\title{
A Potent CD1d-binding Glycolipid for iNKT-Cell-based Therapy Against Human Breast Cancer
}

\author{
TOSHIYUKI SEKI ${ }^{1,2}$, JIANYUN LIU ${ }^{3}$, RANDY R. BRUTKIEWICZ ${ }^{3}$ and MORIYA TSUJI ${ }^{1}$ \\ ${ }^{I}$ Aaron Diamond AIDS Research Center, Affiliate of The Rockefeller University, New York, NY, U.S.A.; \\ ${ }^{2}$ Department of Obstetrics and Gynecology, The Jikei University School of Medicine, Tokyo, Japan; \\ ${ }^{3}$ Department of Microbiology and Immunology, Indiana University School of Medicine, Indianapolis, IN, U.S.A.
}

\begin{abstract}
Background/Aim: Invariant natural killer T-cells (iNKT) stimulated by CDld-binding glycolipids have been shown to exert antitumor effects by a number of studies in a mouse model. Breast cancer is a devastating disease, with different types of breast cancer recurring locally or distant as metastatic/advanced disease following initial treatment. The aim of this study was to examine the tumoricidal effect of a CDIdbinding glycolipid, called 7DW8-5, against a highly invasive human breast cancer cell line both in vitro and in vivo. Materials and Methods: Parental MDA-MB-231 cells and MDA-MB-231 cells transduced with human CDId were labeled with carboxyfluorescein diacetate succinimidyl ester (CFSE), followed by loading with glycolipids. After co-culturing with human iNKT cells, the cells were permeabilized and stained with Alexa Flour 647-conjugated antibody to active caspase-3, and analyzed using a BD LSR II. For the in vivo tumoricidal effect, MDA-MB-231 cells transduced with human CDId and luciferase genes were injected into the mammary fat pad of female NOD/SCID/IL2rynull (NSG) mice, followed by the injection of human iNKT cells with or without 7DW8-5, and the levels of luminescence were analyzed with whole-body imaging. Results: Human iNKT cells could kill CDId-expressing human breast cancer cells in vitro in the presence of 7DW8-5, but not $\alpha$-GalCer. As for in vivo, the adoptive transfer of human iNKT cells into tumor-challenged NSG mice significantly inhibited the growth of CDId + MDA-MB-231 human breast cancer cells in the presence of 7DW8-5. Conclusion: CDId-binding, glycolipidbased iNKT-cell therapy is suggested as a potent and effective treatment against breast cancer in humans.
\end{abstract}

This article is freely accessible online.

Correspondence to: Moriya Tsuji, Aaron Diamond AIDS Research Center, Affiliate of The Rockefeller University, 455 First Ave, New York, NY, 10016, U.S.A. E-mail: mtsuji@adarc.org

Key Words: Natural killer T-cell, CD1d, glycolipid, immunodeficient mice, immunotherapy, invasive human breast cancer.
Breast cancer is a devastating disease, with different types of breast cancer recurring locally $(1,2)$ or distant as metastatic/advanced disease (3) following initial treatment. Metastatic breast cancer usually occurs from months to years after first treatment, and is typically found in the lungs, liver, bones or brain. Nonetheless, breast cancer recurrence is different in each patient; those differences are based on tumor biology (e.g. hormone receptor status), stage of disease when first diagnosed, or even on the chemotherapy received by the patient following diagnosis. A recent and promising treatment approach against various forms of cancer is immunotherapy, which takes advantage of the patient's own immune system to attack the tumor cells.

Natural killer T-cells (NKT) are a unique subset of T-cells that share properties of both T-cells and natural killer cells. NKT cells recognize lipid antigens presented by the non-polymorphic major histocompatibility complex (MHC) class I-like molecule, CD1d (4-6). There are two major subpopulations of NKT cells: Type I NKT cells, also called invariant NKT ( $i$ NKT) cells, and type II NKT cells (7-10). The prototypic antigen for type I NKT cells is $\alpha$-galactosylceramide ( $\alpha$-GalCer), which stimulates $i$ NKT cells to release large amounts of interferon- $\gamma($ IFN $\gamma)$, which helps activate both $\mathrm{CD} 8^{+} \mathrm{T}$-cells and antigen-presenting cells such as dendritic cells (DCs) and macrophages $(11,12)$. Functionally, type I NKT cells exert a protective immune response against tumors (13-17), whereas type II NKT cells are typically associated with immunosuppression $(18,19)$. More recently, we identified a synthetic analog of $\alpha$-GalCer, named 7DW8-5, which elicits the most potent $i$ NKT-cell response among 100 analogs tested (20). As shown in Figure 1A, this analog differs from $\alpha$-GalCer in that it possesses a fluorinated benzene ring at the end of a C8 length fatty acyl chain (20). Thus, 7DW8-5 has been shown to have stronger bioactivity towards $i$ NKT cells and CD1d-bearing DCs (20-26). In addition, 7DW8-5 also has tumoricidal activity against human medulloblastoma in vivo, using humanized mice (17).

In the current study, using a highly invasive and poorly differentiated triple-negative breast cancer cell line, MDAMB-231, we investigated the ability of $\alpha$-GalCer and its 
analog, 7DW8-5, to display NKT cell-dependent cytotoxicity against these human breast cancer cells in vitro; we then analyzed the in vivo antitumor-activating activity of 7DW8-5 using immunodeficient mice.

\section{Materials and Methods}

Animals, glycolipids and a human breast cancer cell line, MDA$M B-231$. A total of 13 female NOD/SCID/IL2r $\gamma$ null (NSG) mice were purchased from The Jackson Laboratory (Bar Harbor, ME, USA) and maintained under specific pathogen-free conditions in the animal facilities at the Comparative Bioscience Center of The Rockefeller University. $\alpha$-GalCer was purchased from Enzo Life Sciences (Farmingdale, NY, USA). 7DW8-5 was synthesized as previously described (20). The structural difference between the two glycolipids is shown in Figure 1A. A human breast cancer cell line, MDA-MB-231, which is a highly aggressive, invasive and poorly differentiated triple-negative breast cancer cell line that lacks estrogen receptor (ER) and progesterone receptor (PR) expression, as well as human epidermal growth factor receptor 2 (27, 28), was purchased from the American Type Culture Collection (Manassas, VA, USA).

A human breast cancer cell line transduced with human CDId and luciferase genes. A human CD1d-human $\beta 2$-microglobulin $(\beta 2 \mathrm{~m})$ $(\mathrm{hCD} 1 \mathrm{~d}-\mathrm{h} \beta 2 \mathrm{~m})$ gene was amplified with polymerase chain reaction from a plasmid consisting of a human CD1d gene covalently linked to a human $\beta 2 \mathrm{~m}$ gene that was previously constructed in our laboratory (26). A firefly luciferase (Luc) gene was amplified from a plasmid that was previously established in our laboratory (29). The amplified hCD1d-h $\beta 2 \mathrm{~m}$ gene and Luc gene were then linked with a T2A linker sequence (ggaagcggagagggcagaggaagtctgctaacatgcggtg acgtcgaggagaatcctggacct). The hCD1d-h $\beta 2 \mathrm{~m}-\mathrm{T} 2 \mathrm{~A}$ linker-Luc gene complex was then inserted into a lentivirus vector, pLV-EF1a-IRESBlast, purchased from Addgene (Cambridge, MA, USA) (30), using a Gibson Assembly ${ }^{\circledR}$ method (New England Biolabs, Ipswich, MA, USA) $(31,32)$. The final constructs were verified with Sanger sequencing. Viral supernatants were produced by the transfection of $5 \times 10^{6} / 10 \mathrm{mI} 293 \mathrm{~T}$-cells in $10-\mathrm{cm}$ petri dishes with $8 \mu \mathrm{g}$ of the CD1dLuc plasmid, and the packaging plasmids, psPAX2 (6.5 $\mu$; Addgene) and pMD2.G ( $2 \mu \mathrm{g}$; Addgene) for $24 \mathrm{~h}$. MDA-MB-231 cells $\left(4 \times 10^{5}\right)$ in 12-well plates were infected with $2 \mathrm{mI}$ of the viral supernatants followed by antibiotic selection with $8 \mu \mathrm{g} / \mathrm{ml}$ of blasticidin. (ThermoFisher Scientific, Waltham, MA, USA). After 16-17 days, the successful infection and transduction of human CD1d were confirmed by staining the infected cancer cell line with an allophycocyaninlabeled anti-human CD1d antibody (BioLegend, San Diego, CA, USA), followed by a flow cytometric assay. The successful transduction and expression of Luc were confirmed by measuring the in vitro firefly luciferase activity, using luminometry (33).

In vitro cytotoxic effects of human iNKT cells against human breast cancer cells. Parental MDA-MB-231 cells and MDA-MB-231 cells transduced with human CD1d were labeled with carboxyfluorescein diacetate succinimidyl ester (CFSE; Molecular Probes, Eugene, OR, USA) $(34,35)$, followed by loading with the respective glycolipid at $0.1 \mu \mathrm{g} / \mathrm{mI}$ for $30 \mathrm{~min}$. Human $i \mathrm{NKT}$ cell lines were established from peripheral blood mononuclear cells, as described elsewhere (36). CFSE-labeled MDA-MB-231 cells pulsed with glycolipid $\left(1 \times 10^{5}\right)$ in $100 \mu \mathrm{l}$ were then mixed with the same number and volume of human $i$ NKT cells as effector cells, in conical polypropylene Costar cluster tubes (Costar, Corning, NY, USA). The cell mixture was centrifuged at low speed $(10 \times g)$ for $1 \mathrm{~min}$ and incubated for $5 \mathrm{~h}$ at $37^{\circ} \mathrm{C}(34,37)$. The cells were then washed with culture media at room temperature, and permeabilized with Cytofix/Cytoperm solution (BD Biosciences, San Jose, CA, USA) for intracellular staining. Next, the cells were washed twice with Perm/Wash buffer (BD Biosciences) and resuspended in staining buffer. After incubation for $1 \mathrm{~h}$ on ice with Alexa Fluor 647conjugated monoclonal antibody to active caspase-3 (BD Biosciences) $(38,39)$, the cells were washed and analyzed using a BD LSR II instrument (BD Biosciences).

A less invasive orthotopic injection of human breast cancer cells into the mammary fat pad of female NSG mice. Human breast cancer cells were inoculated into the mammary fat pad of female NSG mice as described elsewhere (40). Briefly, the mice were first anesthetized using 3\% inhalant isoflurane. Hair around the abdominal and inguinal fat pads was trimmed and the skin was sterilized with alcohol. With the aid of magnifying surgical loupes, a small incision of less than $3 \mathrm{~mm}$ was made externally and caudally to the fourth nipple. The nipple was then lifted, and with the tip of a micro-dissecting scissor blade, the skin was detached from the fascia below and the fat pad exposed. Two million MDA-MB-231/Luc/hCD1d cells were then injected into the fat pad in a small volume $(<100 \mu \mathrm{l})$ using an insulin syringe. With the aid of a Q-Tip dipped in an antibiotic mixture solution, the exposed fat pad was gently pushed inward, allowing it to easily glide back into place. Finally, the small incision was sealed using tissue adhesive (Vetbond; 3M, St Paul, MN, USA), followed by applying post-operative analgesia (bupivacaine) to the area.

Luciferase expression by noninvasive bioluminescent imaging. On 3, 10, 20 and 30 days after intra-mammary fat pad injection of MDA-MB-231/Luc/hCD1d cells, whole-body images of luciferase expression in NSG mice were monitored using IVIS ${ }^{\circledR}$ Lumina with Living Image software (Caliper LifeScience, Hopkinton, MA, USA), as we and others have described $(29,34)$. Briefly, after anesthetizing the mice, $200 \mu \mathrm{l}$ of $15 \mathrm{mg} / \mathrm{ml}$ D-luciferin (Gold Biotechnology, St Louis, MO, USA) was injected intra-peritoneally, and whole-body in vivo imaging analysis was performed for $30 \mathrm{~s}$ to 2 min, using an in vivo imaging system (IVIS ${ }^{\circledR}$ Lumina). Luciferase expression data were then quantified using Living Image software (Caliper LifeScience) in a fixed region of interest in terms of photons $/ \mathrm{s} / \mathrm{cm}^{2} / \mathrm{sr}$.

Data analysis. Statistical analysis of experimental and control data was evaluated by Student's $t$-test. A value of $p<0.05$ was considered statistically significant. Statistical analysis of survival rates was performed by using Gehan-Breslow Wilcoxon test, as previously described (25).

\section{Results}

In vitro cytotoxic effects of human iNKT cells triggered by $\alpha$-GalCer versus 7DW8-5 against human breast cancer cells. We first established a human breast cancer line that expresses human CD1d, namely MDA-MB231/hCD1d, by 
A
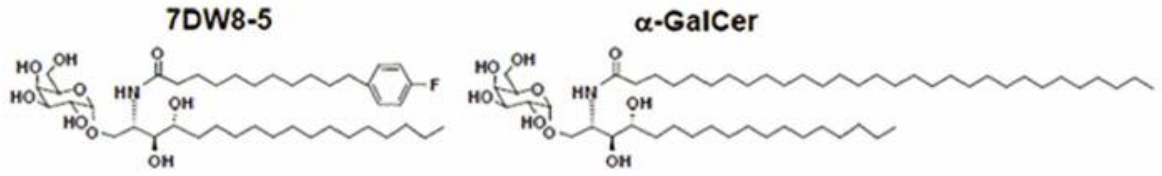

B

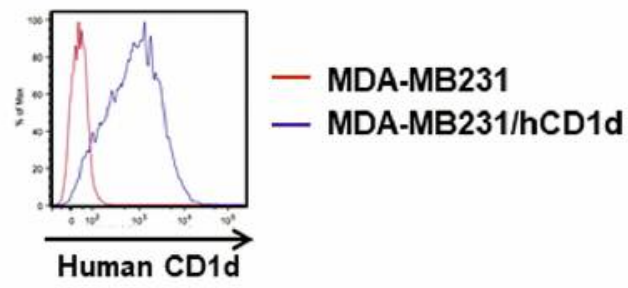

C
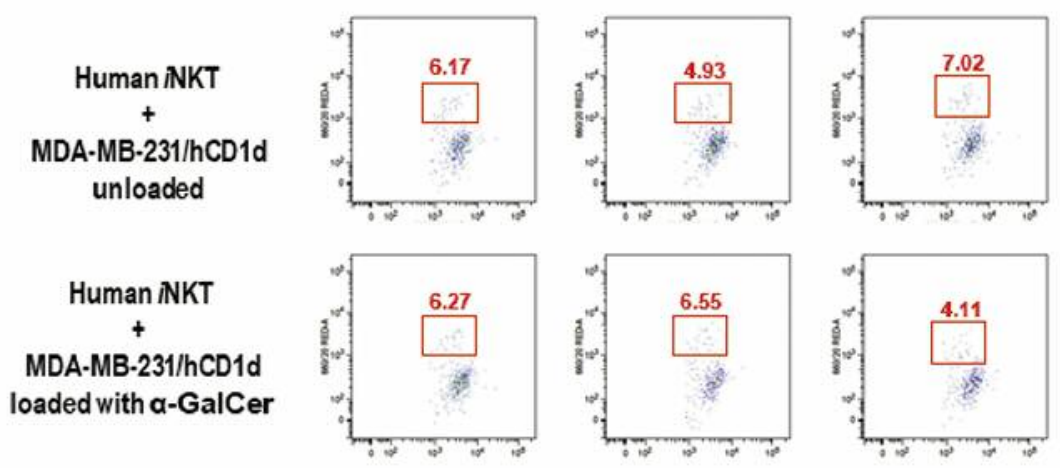

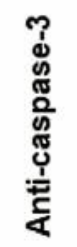
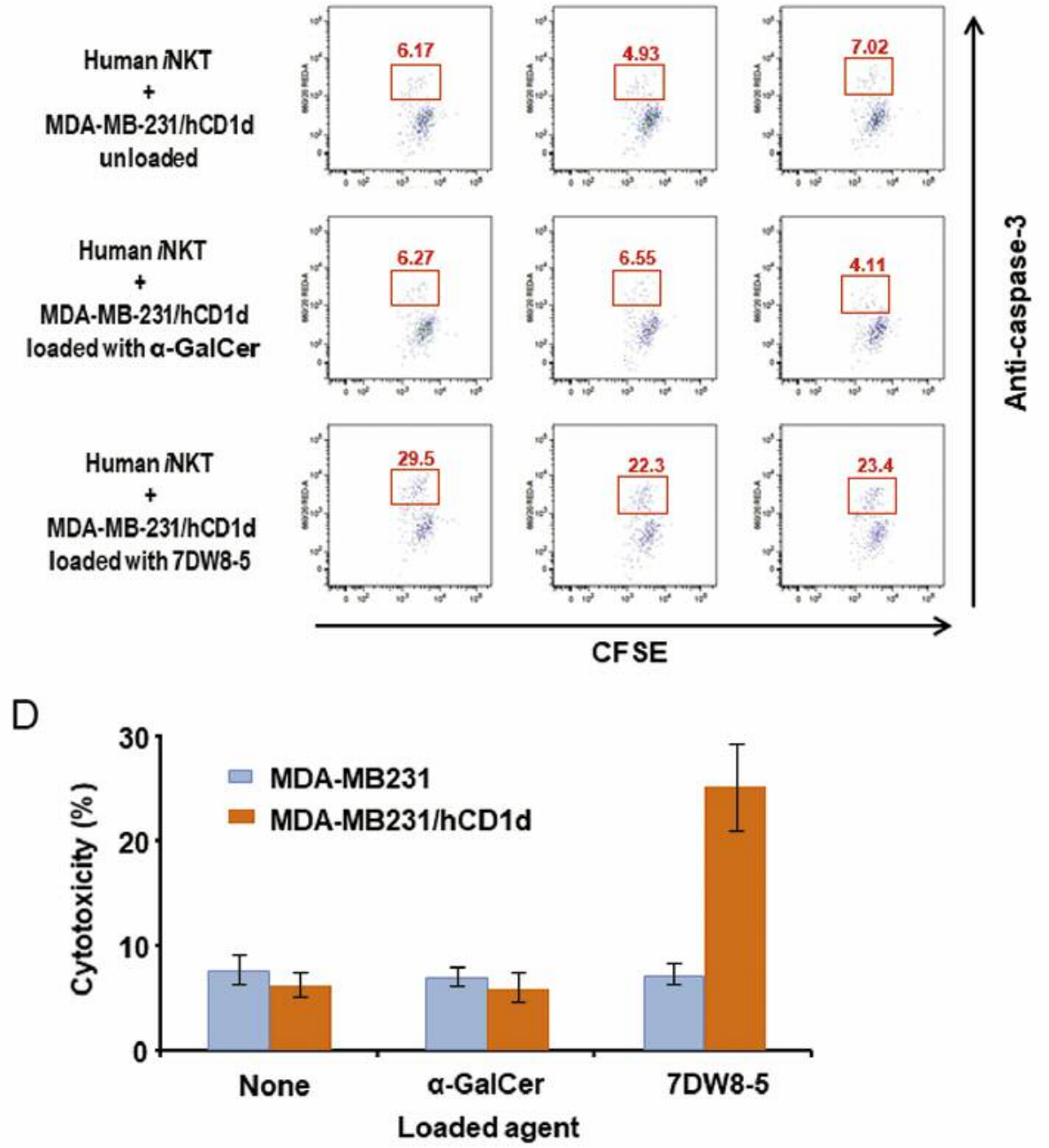

Figure 1. Structure of glycolipids $7 D W 8-5$ and $\alpha$-galactosylceramide $(\alpha$-GalCer) and their ability to trigger cytotoxic activity of human invariant natural killer T- (iNKT) cells against human breast cancer cells in vitro. A: Structural comparison of 7DW8-5 and $\alpha$-GalCer. B: The expression of human CD1d by MDA-MB-231/hCD1d cells, but not by MDA-MB231 cells by flow cytometric analysis. C: Human iNKT cells were used as effector cells. MDA-MB-231 and MDA-MB-231/hCDId cells were labeled with carboxyfluorescein diacetate succinimidyl ester (CFSE), and used as target cells. These two cell populations were co-cultured in the presence or absence of the respective glycolipid, and in-vitro CTL assays were performed by measuring the amount of caspase-3 within the target cells. D: Quantification of the data shown in C. Data are shown from one of three independent experiments with similar results. 
transducing MDA-MB231 line with a plasmid consisting of a human CD1d gene covalently linked to a human $\beta 2 \mathrm{~m}$ gene, as described in the Materials and Methods. Figure 1B shows successful expression of human CD1d by MDAMB231/hCD1d cells as shown by flow cytometric analysis. In order to determine the in vitro cytotoxic activity of $\alpha$ GalCer and its analog 7DW8-5, the human breast cancer lines MDA-MB231 and MDA-MB231/hCD1d were labeled with CFSE, and used as target cells. After establishing human $i$ NKT cell lines, we co-cultured the human breast cancer line with the human $i$ NKT cell line as effector cells in the presence or absence of $\alpha$-GalCer or 7DW8-5. As shown in Figure $1 \mathrm{C}$ and D, we found that human $i$ NKT cells exerted significant in vitro cytotoxic activity against 7DW8-5-pulsed, but not against $\alpha$-GalCer-pulsed or nonpulsed MDA-MB-231 cells that co-expressed human CD1d, as determined by the level of active caspase-3 activity. Neither of the glycolipids was able to induce killing activity against CD1d-deficient MDA-MB-231 cells (Figure $1 \mathrm{C}$ and $\mathrm{D})$.

In vivo tumoricidal effect of 7DW8-5 against human breast cancer cells. Next, we assessed the antitumor effects of 7DW8-5 against the human MDA-MB-231 breast cancer line in vivo using immunodeficient NSG mice. These highly immunodeficient mice lack almost the entire mouse-derived immune system, including murine B-cells, T-cells, and NK cells (41). We first inoculated $2 \times 10^{6}$ MDA-MB231/Luc/hCD1d cells into female NSG mice using a less invasive orthotopic injection into the mammary fat pad (40). Four and 11 days later, $200 \mu \mathrm{l}$ of medium containing $4 \times 10^{6}$ human $i \mathrm{NKT}$ cells and $0.1 \mu \mathrm{g}$ of 7DW8-5, or human $i \mathrm{NKT}$ cells only or PBS as a control, was administered intravenously to a group of tumor-challenged mice. Finally, we assessed the levels of luminescence by whole-body in vivo imaging on days 3, 10, 20 and 30 post-tumor inoculation (Figure 2A). We first ensured that the tumor masses were established in all NSG mice challenged with MDA-MB-231/Luc/hCD1d cells before treating with human $i$ NKT cells/7DW8-5, as determined by IVIS (Figure 2C). We then observed that both groups of NSG mice that received human $i$ NKT cells and 7DW8-5, as well as human $i$ NKT cells only, showed a lower luciferase signal on day 27 post treatment (Figure 2B and C). Nevertheless, a statistical difference was only observed between a group of NSG mice that received human $i \mathrm{NKT}$ cells and 7DW8-5, as compared with PBS-treated mice (Figure 2C). Furthermore, compared to the PBS-treated mice, all four NSG mice that received human $i$ NKT cells and 7DW8-5 survived significantly longer upon tumor challenge (Figure 2D). When we challenged mice with MDA-MB-231/Luc cells that lacked human CD1d gene expression, the glycolipids failed to exert a significant antitumor effect (data not shown).

\section{Discussion}

NKT cells, an innate cytotoxic lymphocyte subset, are possessed by all humans $(7,8)$. In addition, the CD1d molecule, which is highly conserved (4-6) and expressed by some breast cancer cells $(29,43)$, is able to present a glycolipid, such as 7DW8-5 and its parental glycolipid, $\alpha$-GalCer, both of which activate NKT cells. 7DW8-5, which possesses a much stronger stimulatory activity against NKT cells than $\alpha$-GalCer, has already been shown to display a more potent antitumor effect than $\alpha$-GalCer in mice (17). Therefore, it is conceivable that 7DW8-5 elicits a potent NKT cell-directed attack on CD1d-expressing breast cancer cells in humans. In the current study, we demonstrated that human $i$ NKT cells are able to kill CD1d-expressing human breast cancer cells in vitro in the presence of 7DW8-5, but not $\alpha$-GalCer. The distinct difference in the ability of the two glycolipids to mediate in vitro killing by human $i$ NKT cells may be due to the difference in their binding affinity to CD1d (20) but further investigation is needed to clarify the issue.

For in vivo tumoricidal effects, we opted to test only 7DW8-5, as $\alpha$-GalCer failed to stimulate antitumor effects of human $i$ NKT cells in vitro. Since NSG mice lack almost all mouse-derived adaptive immunity, as well as NK cells (42), it was possible for human $i \mathrm{NKT}$ cells to be adoptively transferred to NSG mice without facing an immediate GVH reaction, allowing us to observe the activity of human $i \mathrm{NKT}$ cells in vivo for several weeks. Although not statistically significantly, the adoptive transfer of human $i$ NKT cells appeared to suppress tumor growth compared to PBS-treated NSG mice. It is possible that human $i$ NKT cells may recognize endogenous glycolipids in the context of CD1d molecules expressed by the tumor. Nevertheless, the inclusion of 7DW8-5 concomitant with the adoptive transfer of human $i$ NKT cells into tumor-challenged NSG mice significantly inhibited the growth of CD1d ${ }^{+}$MDA-MB-231 human breast cancer cells. In addition, it is noteworthy that the co-administration of human $i$ NKT cells and 7DW8-5 to a group of tumor-bearing NSG mice resulted in a significant $(p<0.05)$ increase in the survival rate of mice compared with that of PBS-treated NSG mice. 7DW8-5 failed to display its antitumor effect against human breast cancer cells that did not express human CD1d. In this regard, it is certainly imperative to investigate whether 7DW8-5 is able to trigger antitumor effects of human $i \mathrm{NKT}$ cells in vivo in the presence of other cell populations, such as DCs and macrophages that highly express human CD1d molecules. It is also plausible that 7DW8-5 would act as an adjuvant to enhance tumor antigen-specific $\mathrm{CD}^{+}$T-cells $(25,43)$, which in turn can attack human breast cancer cells regardless of CD1d expression. The availability of a humanized mouse model, which possesses an almost entire human immune system that includes not only human $i$ NKT cells but also 


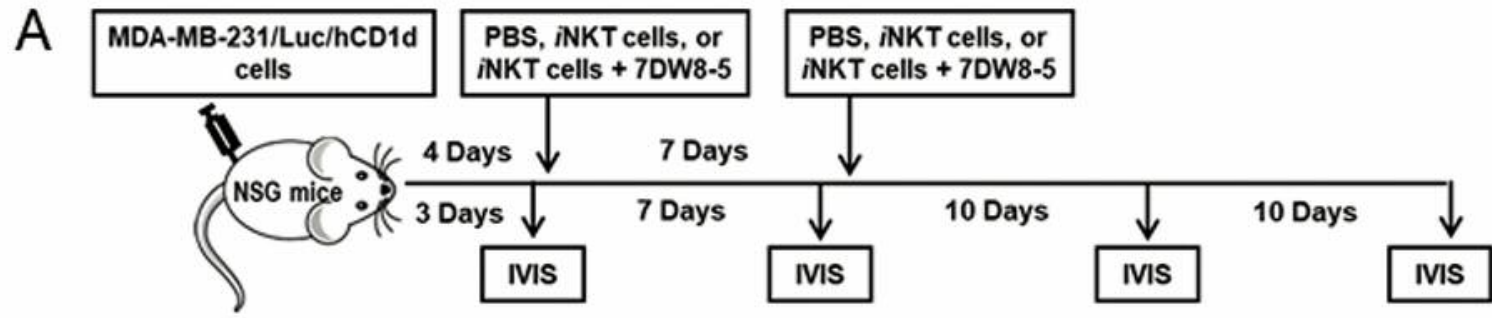

B

Day 30 after MDA-MB-231/Luc/hCD1d challenge

Treated with:

PBS

Human iNKT cells

Human iNKT cells + 7DW8-5
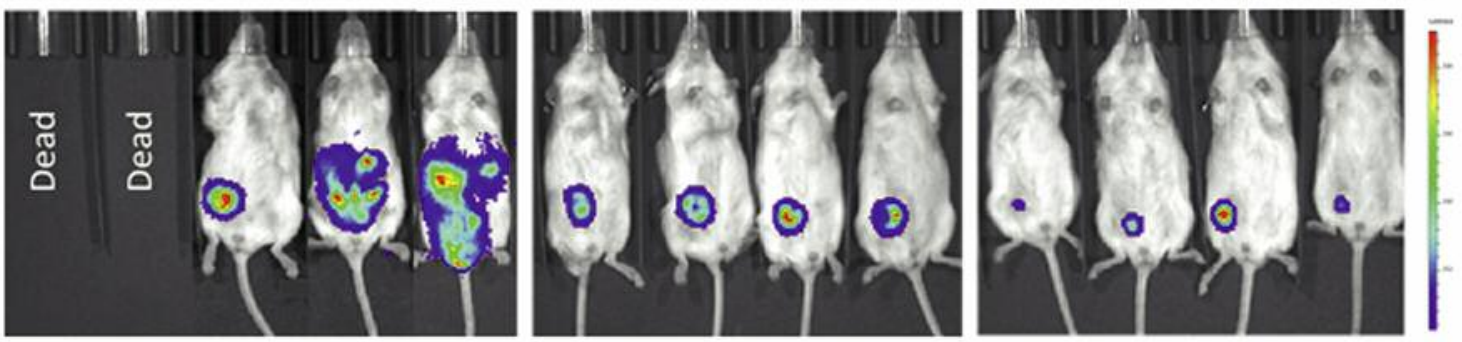

C

Post MB-231 challenge: Day 3

Day 10

Day 20

Day 30
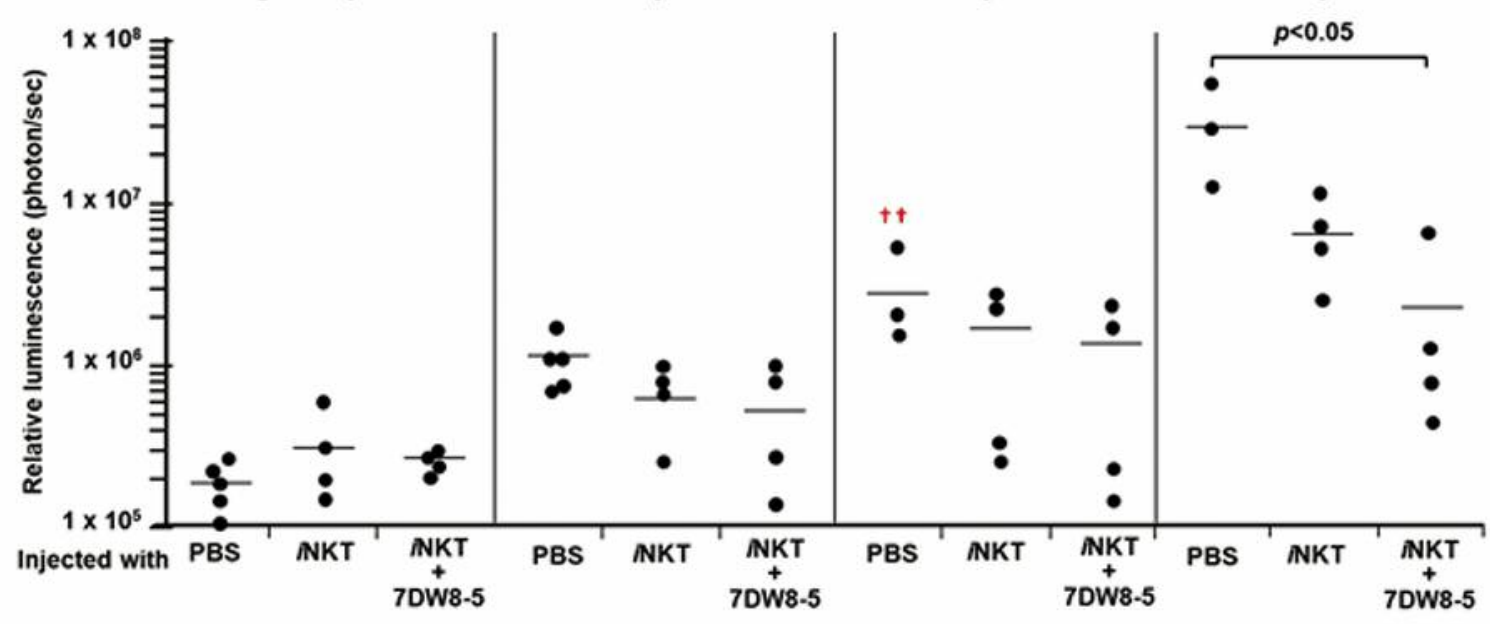

D

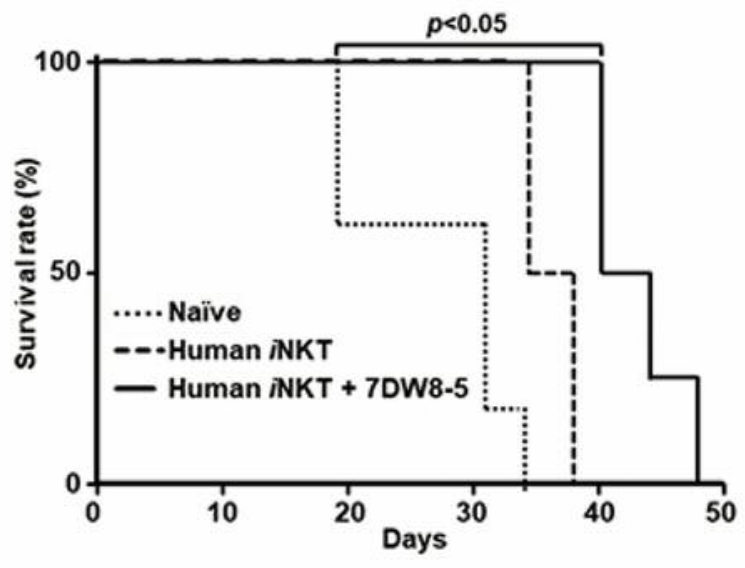

Figure 2. Experimental scheme and IVIS results showing the in-vivo tumoricidal effects of human invariant natural killer T- (iNKT) cells in the presence of glycolipid 7DW8-5. A: Schematic representation of the experimental procedure for testing in-vivo tumoricidal activity upon the adoptive transfer of human iNKT cells together with and without 7DW8-5. $B$ : Non-invasive bioluminescence imaging depicting luciferase expression in the mammary fat pad, 30 days after injection with MDA-MD-231 cells co-expressing luciferase and human CDId. A group of five mice were treated with phosphate-buffered saline (PBS), whereas groups of four mice each were adoptively transferred with human iNKT cells or human iNKT cells with 7DW8-5. C: The graphs show the bioluminescent signal intensity in the region of interest (ROI), calculated as photons $/ \mathrm{s} / \mathrm{cm}^{2} / \mathrm{sr}$, of all groups on days 3, 10, 20 and 30 post-MDA-MB-231/Luc/hCD1d challenge. D: Survival rate of groups of MDA-MB-231/Luc/hCD1d-challenged female NSG mice that received human iNKT cells with and without 7DW8-5, or $P B S$ as a control. Statistical analysis of survival rates was performed using the Gehan-Breslow Wilcoxon test. The data shown are from one of three independent experiments with similar results. 
$\mathrm{CD}^{+}$T-cells and DCs $(26,34,44)$, will enable us to address this aforementioned issue.

In conclusion, we believe that our current study has provided a proof of principle for using 7DW8-5 as a novel and potent anticancer immunotherapeutic agent in vivo, particularly against human $\mathrm{CD} 1 \mathrm{~d}^{+}$tumors. This initial finding dictates the necessity of a more in-depth mechanistic study, to investigate the mode of action and efficacy of 7DW8-5 against a myriad of human cancer cells.

\section{Conflicts of Interest}

The Authors have no conflict of interest in regard to this study.

\section{Authors' Contributions}

Designed studies: All Authors. Performed assays: TS, MT. Analyzed data: All Authors. Wrote manuscript: TS, MT. Reviewed manuscript: All Authors.

\section{Acknowledgements}

The Authors would like to thank Vincent Sahi for his assistance with flow cytometry and Yukiko Tsuji for her technical assistance. This work was in part supported by grants from the National Institutes of Health (R01-AI070258) and the Ryota Funakoshi Foundation.

\section{References}

1 Carlson RW: Surveillance of patients following primary therapy. In: Diseases of the Breast. Harris JR, Lippman ME, Morrow M and Osborne CK (ed.). Lippincott, Williams and Wilkins, Philadelphia, PA. 2014.

2 Colleoni M, Sun Z, Price KN, Karlsson P, Forbes JF, Thürlimann B, Gianni L, Castiglione M, Gelber RD, Coates AS and Goldhirsch A: Annual hazard rates of recurrence for breast cancer during 24 years of follow-up: Results from the International Breast Cancer Study Group Trials I to V. J Clin Oncol 34: 927-935, 2016. PMID: 26786933, DOI: 10.1200/JCO.2015.62.3504

3 Harris JR and Morrow M: Breast-conserving therapy. In: Diseases of the Breast. Harris JR, Lippman ME, Morrow M and Osborne CK (ed.). Lippincott, Williams and Wilkins, Philadelphia, PA. 2014.

4 Kronenberg M: Toward an understanding of NKT cell biology: Progress and paradoxes. Annu Rev Immunol 23: 877-900, 2005. PMID: 15771592, DOI: 0.1146/annurev.immunol. 23.021704. 115742

5 Bendelac A., Savage PB and Teyton L: The biology of NKT cells. Annu Rev Immunol 25: 297-336, 2007. PMID: 17150027, DOI: 10.1146/annurev.immunol.25.022106.141711

6 Brigl M and Brenner MB: CD1: Antigen presentation and T-cell function. Annu Rev Immunol 22: 817-890, 2004. PMID: 15032598, DOI: 10.1146/annurev.immunol.22.012703.104608

7 Lantz $\mathrm{O}$ and Bendelac A: An invariant T-cell receptor alpha chain is used by a unique subset of major histocompatibility complex class I-specific CD4+ and CD4-8- T-cells in mice and humans. J Exp Med 180: 1097-1106, 1994. PMID: 7520467
8 Dellabona P, Padovan E, Casorati G, Brockhaus $M$ and Lanzavecchia A: An invariant $\mathrm{V} \alpha 24-\mathrm{J} \alpha \mathrm{Q} / \mathrm{V} \beta 11 \mathrm{~T}$-cell receptor is expressed in all individuals by clonally expanded $\mathrm{CD}^{-} 8^{-} \mathrm{T}-$ cells. J Exp Med 180: 1171-1176, 1994. PMID: 8064234, DOI: 10.1084/jem.180.3.1171

9 Behar SM, Podrebarac TA, Roy CJ, Wang CR and Brenner MB: Diverse TCRs recognize murine CD1. J Immunol 162: 161-167, 1999. PMID: 9886382

10 Cardell BS, Tangri S, Chan S, Benoist C and Mathis D: CD1restricted $\mathrm{CD}^{+}{ }^{+} \mathrm{T}$-cells in major histocompatibility complex class II-deficient mice. J Exp Med 182: 993-1004, 1995. PMID: 7561702

11 Taraban VY, Martin S, Attfield KE, Glennie MJ, Elliott T, Elewaut D, Van Calenbergh S, Linclau B and Al-Shamkhani A: Invariant NKT cells promote $\mathrm{CD} 8+$ cytotoxic T-cell responses by inducing CD70 expression on dendritic cells. J Immunol 180: 4615-4620, 2008. PMID: 18354184

12 Fujii S, Shimizu K, Smith C, Bonifaz L and Steinman RM: Activation of natural killer T-cells by alpha-galactosylceramide rapidly induces the full maturation of dendritic cells in vivo and thereby acts as an adjuvant for combined CD4 and CD8 T-cell immunity to a co-administered protein. J Exp Med 198: 267-279, 2003. PMID: 12874260, DOI: 10.1084/jem.20030324

13 Kawano T, Cui J, Koezuka Y, Toura I, Kaneko Y, Sato H, Kondo E, Harada M, Koseki H, Nakayama T, Tanaka Y and Taniguchi M: Natural killer-like nonspecific tumor cell lysis mediated by specific ligand-activated Valpha14 NKT cells. Proc Natl Acad Sci USA 95: 5690-5693, 1998. PMID: 9576945

14 Crowe NY, Smyth MJ and Godfrey DI: A critical role for natural killer T-cells in immunosurveillance of methylcholanthreneinduced sarcomas. J Exp Med 196: 119-127, 2002. PMID: 12093876

15 Pilones KA, Aryankalayil J and Demaria S: Invariant NKT cells as novel targets for immunotherapy in solid tumors. Clin Dev Immunol 2012:720803, 2012. PMID: 23118781

16 Altman JB, Benavides AD, Das R and Bassiri H: Antitumor responses of invariant natural killer T-cells. J Immunol Res 2015: 652875, 2015. PMID: 26543874, DOI: 10.1155/2012/720803

17 Liu D, Song L, Brawley VS, Robison N, Wei J, Gao X, Tian G, Margol A, Ahmed N, Asgharzadeh S and Metelitsa LS: Medulloblastoma expresses CD1d and can be targeted for immunotherapy with NKT cells. Clin Immunol 149: 55-64, 2013. PMID: 23891738, DOI: 10.1016/j.clim.2013.06.005

18 Moodycliffe AM, Nghiem D, Clydesdale G and Ullrich SE: Immune suppression and skin cancer development: regulation by NKT cells. Nat Immunol 1: 521-525, 2000. PMID: 11101875, DOI: $10.1038 / 82782$

19 Terabe M, Matsui S, Noben-Trauth N, Chen H, Watson C, Donaldson DD, Carbone DP, Paul WE and Berzofsky JA: NKT cell-mediated repression of tumor immunosurveillance by IL-13 and the IL-4R-STAT6 pathway. Nat Immunol 1: 515-520, 2000. PMID: 11101874 , DOI: $10.1038 / 82771$

20 Li X, Wu D, Fujio M, Imamura M, Vasan S, Wong C-H, Ho DD and Tsuji M: Design of a potent CD1d-binding NKT cell ligand as a vaccine adjuvant. Proc Natl Acad Sci USA 107: 1301013015, 2010. PMID: 20616071, DOI: 10.1073/pnas.1006662107

21 Padte NN, Boente-Carrera M, Andrews CD, McManus J, Grasperge BF, Gettie A, Coelho-dos-Reis JG, Li X, Wu D, Bruder JT, Sedegah M, Patterson N, Richie TL, Wong CH, Ho DD, Vasan S and Tsuji M: A glycolipid adjuvant 7DW8-5, enhances $\mathrm{CD}^{+} \mathrm{T}$-cell responses 
induced by an adenovirus-vectored malaria vaccine in non-human primates. PLoS One 8: e78407, 2013. PMID: 24205224, DOI: 10.1371/journal.pone.0078407

22 Padte NN, Li X, Tsuji M and Vasan S: Clinical development of a novel CD1d-binding NKT cell ligand as a vaccine adjuvant. Clin Immunol 140: 142-151，2011. PMID: 21185784, DOI: 10.1016/j.clim.2010.11.009

23 Li X, Kawamura A, Andrews CD, Miller JL, Wu D, Tsao T, Zhang M, Oren D, Padte NN, Porcelli SA, Wong CH, Kappe SH, Ho DD and Tsuji M: The co-localization of a CD1d-binding glycolipid with a radiation-attemuated sporozoites vaccine in LN-resident DCs for a robust adjuvant effect. J Immunol 195: 2710-2721, 2015. PMID: 26254338, DOI: 10.4049/jimmunol.1403017

24 Li X, Huang J, Kawamura A, Funakoshi R, Porcelli SA and Tsuji $\mathrm{M}$ : Co-localization of a CD1d-binding glycolipid with an adenovirus-based malaria vaccine for a potent adjuvant effect. Vaccine 35: 3171-3177, 2017. PMID: 28483194, DOI: 10.1016/j.vaccine.2017.04.077

25 Coelho-dos-Reis JG, Huang J, Tsao T, Pereira FV, Funakoshi R, Nakajima $H$, Sugiyama $H$ and Tsuji M: Co-administration of $\alpha-$ GalCer analog and TLR4 agonist induces robust CD8+ T-cell responses to PyCS protein and WT-1 antigen and activates memory-like effector NKT cells. Clin Immunol 168: 6-15, 2016. PMID: 27132023, DOI: 10.1016/j.clim.2016.04.014

26 Li X, Huang J, Kaneko I, Zhang M, Iwanaga S, Yuda M and Tsuji M: A potent adjuvant effect of a CD1d-binding NKT cell ligand in human immune system mice. Expert Rev Vaccines 16: 73-80, 2017. PMID: 27801602, DOI: $10.1080 / 14760584.2017 .1256208$

27 El Guerrab A, Zegrour R, Nemlin CC, Vigier F, Cayre A, PenaultLlorca F, Rossignol F and Bignon YJ: Differential impact of EGFR-targeted therapies on hypoxia responses: Implications for treatment sensitivity in triple-negative metastatic breast cancer. PLoS One 6: e25080, 2011. PMID: 21966417, DOI: 10.1371/ journal.pone. 0025080

28 Hix LM, Shi YH, Brutkiewicz RR, Stein PL, Wang CR and Zhang M: CD1d-expressing breast cancer cells modulate NKT cellmediated antitumor immunity in a murine model of breast cancer metastasis. PLoS One 6: e20702, 2011. PMID: 21695190, DOI: 10.1371/journal.pone.0020702

29. Rai U, Huang J, Mishra S, Li X, Shiratsuchi T and Tsuji M: A new method to determine antigen-specific CD8+ T-cell Activity in vivo by hydrodynamic injection. Biomolecules 2: 23-33, 2012. PMID: 24970125, DOI: 10.3390/biom2010023

30. Hayer A, Shao L, Chung M, Joubert LM, Yang HW, Tsai FC, Bisaria A, Betzig E and Meyer T: Engulfed cadherin fingers are polarized junctional structures between collectively migrating endothelial cells. Nat Cell Biol 18: 1311-1323, 2016. PMID: 27842057, DOI: $10.1038 /$ ncb3438

31. Gibson DG, Young L, Chuang RY, Venter JC, Hutchison CA 3rd and Smith HO: Enzymatic assembly of DNA molecules up to several hundred kilobases. Nat Methods 6: 343-345, 2009. PMID: 19363495, DOI: 10.1038/nmeth.1318

32. Gibson DG, Glass JI, Lartigue C, Noskov VN, Chuang RY, Algire MA, Benders GA, Montague MG, Ma L, Moodie MM, Merryman C, Vashee S, Krishnakumar R, Assad-Garcia N, Andrews-Pfannkoch C, Denisova EA, Young L, Qi ZQ, SegallShapiro TH, Calvey CH, Parmar PP, Hutchison CA 3rd, Smith $\mathrm{HO}$ and Venter JC: Creation of a bacterial cell controlled by a chemically synthesized genome. Science 329: 52-56, 2010. PMID: 20488990, DOI: 10.1126/science.1190719
33 Kim JB, Urban K, Cochran E, Lee S, Ang A, Rice B, Bata A, Campbell K, Coffee R, Gorodinsky A, Lu Z, Zhou H, Kishimoto TK and Lassota P: Non-invasive detection of a small number of bioluminescent cancer cells in vivo. PLoS One 5: e9364, 2010. PMID: 20186331, DOI: 10.1371/journal.pone.0009364

34 Huang J, Li X, Coelho-dos-Reis JG, Wilson JM and Tsuji M: An AAV vector-mediated gene delivery approach facilitates reconstitution of functional human $\mathrm{CD}^{+}{ }^{+} \mathrm{T}$-cells in mice. PLoS One 9: e88205, 2014. PMID: 24516613, DOI: 10.1371/ journal.pone. 0088205

$35 \mathrm{Li} \mathrm{WC}$, Ralphs KL and Tosh D: Isolation and culture of adult mouse hepatocytes. Methods Mol Biol 633: 185-196, 2010. PMID: 20204628, DOI: 10.1007/978-1-59745-019-5_13

$36 \mathrm{Li} \mathrm{X}$, Tsuji M, Schneck J and Webb TJ: Generation of human $i$ NKT cell lines. Bio Protoc 3: pii: e418, 2013. PMID: 27570795

37 Fujioka H, Hunt PJ, Rozga J, Wu GD, Cramer DV, Demetriou AA and Moscioni AD: Carboxyfluorescein (CFSE) labelling of hepatocytes for short-term localization following intraportal transplantation. Cell Transplant 3: 397-408, 1994. PMID: 7827777

38 Jerome KR, Sloan DD and Aubert M: Measurement of CTLinduced cytotoxicity: The caspase 3 assay. Apoptosis 8: 563-571, 2003. PMID: 14574062, DOI: 10.1023/A:1026123223387

39 He L, Hakimi J, Salha D, Miron I, Dunn P and Radvanyi L: A sensitive flow cytometry-based cytotoxic T-lymphocyte assay through detection of cleaved caspase 3 in target cells. J Immunol Methods 304: 43-59, 2005. PMID: 16076473, DOI: 10.1016/j.jim.2005.06.005

40 Tavera-Mendoza LE and Brown M: A less invasive method for orthotopic injection of breast cancer cells into the mouse mammary gland. Lab Anim 51: 85-88, 2017. PMID: 26994106, DOI: $10.1177 / 0023677216640706$

41 Shultz LD, Lyons BL, Burzenski LM, Gott B, Chen X, Chaleff S, Kotb M, Gillies SD, King M, Mangada J, Greiner DL and Handgretinger R: Human lymphoid and myeloid cell development in NOD/LtSz-SCID IL2R gamma null mice engrafted with mobilized human hematopoietic stem cells. J Immunol 174: 6477-6489, 2005. PMID: 15879151

42. Golmoghaddam H, Pezeshki AM, Ghaderi A and Doroudchi M: $\mathrm{CD} 1 \mathrm{a}$ and CD1d genes polymorphisms in breast, colorectal and lung cancers. Pathol Oncol Res 17: 669-675, 2011. PMID: 21258883, DOI: $10.1007 / \mathrm{s} 12253-011-9367-\mathrm{x}$

43. Xu X, Hegazy WA, Guo L, Gao X, Courtney AN, Kurbanov S, Liu D, Tian G, Manuel ER, Diamond DJ, Hensel M and Metelitsa LS: Effective cancer vaccine platform based on attenuated salmonella and a type III secretion system. Cancer Res 74: 6260-70, 2014. PMID: 25213323, DOI: 10.1158/00085472.CAN-14-1169

44. Li X, Huang J, Zhang M, Funakoshi R, Sheetij D, Spaccapelo R, Crisanti A, Nussenzweig V, Nussenzweig RS and Tsuji M: Human $\mathrm{CD}^{+} \mathrm{T}$-cells mediate protective immunity induced by a human malaria vaccine in human immune system mice. Vaccine 34: 4501-4506, 2016. PMID: 27502569, DOI: 10.1016/ j.vaccine. 2016.08 .006
Received January 4, 2019

Revised January 18, 2019

Accepted January 22, 2019 